\section{Limited Evidence Suggests Benefits of Single Visit Revascularization Endodontic Procedures - A Systematic Review}

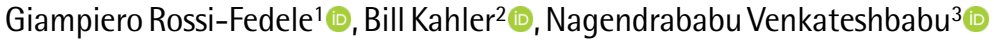

\begin{abstract}
Revascularization endodontic procedures commonly require multiple treatment sessions. However, single visit procedures may be advantageous from the clinical and patient management standpoints. The purpose of this review was to evaluate the outcomes of single-visit revascularization endodontic procedures for the management of immature permanent teeth with non-vital pulp. Two electronic databases (Scopus and PubMed) were searched, from their inception to July 2018 , for studies that assessed clinical and/ or radiographic and/or histologic outcomes of single-visit revascularization endodontic procedures performed in immature permanent teeth with non-vital pulp. Case reports, animal studies and clinical trials were included. The quality of case reports was appraised by Joanna Briggs Institute Critical Appraisal Checklist for Case Reports. The quality of randomized clinical trials was assessed by the revised Cochrane risk of bias tool for randomized trials. The risk of bias for animal studies was assessed using SYRCLE's risk of bias tool. Tabulation followed by narrative synthesis was used to draw conclusions. Seven studies satisfied the selection criteria. Five were classified as case reports, one as a randomized clinical trial and one as animal study. The latter presented with a high risk of bias, whilst the remaining showed a low risk. The evidence supporting the potential use of single-visit revascularization endodontic procedures is scarce. Successful single-visit revascularization endodontic procedures commonly include the use of high concentrations of sodium hypochlorite and EDTA combined with the use of agitation systems. Further clinical trials with long term follow up are needed to confirm the results of the current review.
\end{abstract}

'Adelaide Dental School,

The University of Adelaide, Adelaide, Australia

${ }^{2}$ School of Dentistry, The University of Queensland, Brisbane, Australia ${ }^{3}$ School of Dentistry, International Medical University, Kuala Lumpur, Malaysia

Correspondence: Prof. Giampiero Rossi-Fedele, Adelaide Dental School, AHMS 10th floor, George Street C/0 North Terrace, Adelaide, SA 5005, Australia. Tel: +61-88313-8139. e-mail: giampiero. rossi-fedele@adelaide.edu.au

Key Words: endodontics, dental pulp, necrosis, regeneration, root canal.

\section{Introduction}

Trauma or caries in immature permanent teeth can result in necrosis of the pulp and cessation of the root development process, leaving thin and fragile root canal walls (1). Subsequently, non-vital immature teeth are associated with a high risk of root fracture, because of their inability to sustain physiological mastication forces and further trauma (1). The management of immature permanent teeth with a non-vital pulp is a demanding procedure for clinicians (2,3). Amongst the possible treatment alternatives, calcium hydroxide multi-visit apexification (4), apical barrier techniques using tricalciumsilicate based materials $(5,6)$ and revascularization endodontic procedures (REPs) (7) have been proposed. Whilst calcium hydroxide multi-visit apexification and apical barrier techniques are not associated with further root maturation (8), REPs are associated with root length and wall thickness increased together with reduction in apical diameter (8). The aim of this root maturation is to reduce the risk of tooth fracture.

REPs published protocols commonly require the use of an intermediate medicament following chemo-mechanical preparation, thus with a two-visit approach (7-9). The drawbacks in two visit REPs are the need for increased visits, placement of temporary restorative materials, patient compliance and longer treatment time $(10,11)$. Single-visit REPs would be particularly advantageous when general anaesthesia is required. Further issues related to the use of intracanal medicament in REP are discoloration of tooth $(11,12)$, reduced fracture resistance of tooth (13), detrimental effect on apical papilla stem cells survival (14) and their retrieval from root canal walls (15). To overcome these issues, and to achieve a significant saving in time and cost for patients and dentists (16) single visit REPs could be an alternative method. In fact, apical barrier techniques (17), and non-surgical root canal treatment (16), can be performed with a single-visit protocol. Thus, it is worth investigating if a single-visit approach for REPs is effective and safe. To the knowledge of authors, no review has been published to critically appraise the evidence on single visit REPs and the topic has received limited attention in the literature. Hence, the aim of the current systematic review was to evaluate the published outcomes of single visit REPs for the management of immature permanent tooth with non-vital pulp. The research question for the present systematic review was designed according to the 
PEO (Population; Exposure of interest; Outcome) format: "In studies managing non-vital immature permanent teeth (P) treated with a single-visit REPs (E), what are the clinical AND/OR radiographic AND/OR histological outcomes (0)?"

\section{Material and Methods}

\section{Literature Search Process}

Initially, PubMed was explored for screening of search terms pertinent to the research question using sentinel studies as a reference. The search strategy was developed from the appropriately identified key words and index terms and applied in combination, by using Boolean terms (OR/AND), to the selected databases. Two reviewers independently (VN, GRF) performed a literature search in PubMed and Scopus databases from inception to July 2018 by using search strategy ((((regenerative endodontic) OR revascularization) OR revitalization)) AND ((immature permanent tooth) $\mathrm{OR}$ immature permanent teeth). The title and the abstract of the published studies were evaluated independently by two reviewers (VN, GRF) and, if not clear enough, the full text of the article was read for accuracy of data gathering. After title and abstract screening, full text evaluation of the relevant articles was performed to identify their eligibility against the selection criteria. The additional search was undertaken from the reference lists of the included articles and previously published reviews, using the same selection criteria. Any disagreements between two reviewers was resolved by team discussion or with the third reviewer (BK).

\section{Selection Criteria}

Inclusion criteria for our review were: single visit REPs performed in immature permanent tooth with non-vital pulp, with no exclusions based on study design. Reviews and studies in the form of conference proceedings, letters or commentaries, and publications without abstracts were excluded. The search was limited to publications written in English.

\section{Outcome of Interest}

The outcome of the review was clinical and/or radiographic and/or histologic outcome of single visit REPs performed in immature permanent teeth with nonvital pulp.

\section{Data Extraction Process}

Two independent reviewers (VN, GRF) performed data extraction process. After piloting, the data extraction form was produced and consisted of first author, year, country, study design, pulpal and periapical pre-treatment diagnosis, pre-operative radiographic findings, intraoperative disinfection protocol, intracanal coronal barrier, duration of follow up, clinical and/or radiographic/and or histological outcomes. In addition, further data collected included, for clinical studies, the age and the gender of the subject(s), aetiology of the loss of vitality, tooth type and sample size, whilst for animal studies the animal species, tooth type and sample size. Authors of the included studies were contacted for clarification and/or requested to provide further information as needed.

\section{Quality and Risk of Bias Assessment of Included Studies}

Two independent reviewers (VN, GRF) appraised the quality of included studies. Disagreements between the reviewers at the different stages of the review were resolved by discussion. The quality of included case reports was assessed by Joanna Briggs Institute Critical Appraisal Checklist for Case Reports which consist of eight yes/no/ unclear questions (18). The quality of randomized clinical trial was assessed by the revised Cochrane risk of bias tool for randomized trials (RoB 2.0) (19). Finally, the risk of bias for animal studies was assessed using SYRCLE's risk of bias tool for animal studies (20).

To summarize the overall quality of case reports and animal study, these were grouped into the following categories 1. Low risk of bias (studies that met at least $75 \%$ of the quality criteria) 2. Moderate risk of bias (studies that met between $50 \%$ and $74 \%$ of the quality criteria) 3. High risk of bias (studies that met less than $49 \%$ of the quality criteria).

The overall quality of the randomized clinical trial was assessed: A "low risk" of bias score was given to a study when all the key domains in the assessment of bias were found to be of low risk. When one of the key domains in the bias assessment was found to have some concerns, a scoring of "some concerns" was accorded. The assessment of at least one key domain of bias with a high risk in a study rendered it to be of "high risk" of bias.

\section{Data Synthesis}

Following tabulation narrative synthesis was used to draw conclusions.

\section{Results}

A total of 359 studies were identified from electronic databases, 164 studies were removed as duplicates. Among the 195 studies, seven satisfied the criteria. Five were classified as case reports $(10,21-24)$, one as a randomized clinical trial (25) and one as an animal study (26). Main characteristics of the included case reports, clinical trial and animal study were reported in Tables 1,2 and 3 respectively. Case reports and the animal study included presented with favorable outcomes, whereas the randomized controlled 
trial reported a fifty-percent success rate.

The authors of two studies were contacted, firstly for clarification of pulpal and periapical pre-treatment diagnosis, pre-operative radiographic findings and aetiology of the loss of vitality at the different stages of the study (25), and the second regarding some features of the study design (26), as this was not able to be determined by the data provided in the identified studies. Of these authors, one provided some of the requested information (25), with the second not replying. Figure 1 shows the summary of the details and results of the search process.

\section{Discussion}

The current review aims to obtain a narrative integration of the relevant evidence regarding the outcome of single visit REPs for the management of immature permanent tooth. Within the paucity of studies, positive outcomes appear to be associated with the use of sodium hypochlorite $(\mathrm{NaOCl})$ and EDTA as root canal irrigant solutions, in the presence of adequate dynamics of irrigation, namely the volume and agitation of the irrigant. The present review includes five case reports, one randomized clinical trial and one animal study to assess the outcome of single visit REPs. This approach has been followed due to limited number of studies in the review, however this is consider acceptable as allows to integrate the richness of the qualitative research currently available to capture the whole phenomenon of interest (27).

Case reports help us to gain knowledge and information on any new observation or procedure, report on rare diseases or conditions, generate hypothesis and research question on a problem and thus serves as an important educational tool and clinical resource (28). Generally, case reports/series are at the lowest level of the evidence pyramid due to increased risk of bias (29) but have played an important role in the evidence network (30). They form the first level of evidence in many instances which leads to well-designed observational or interventional studies. In the specific case of REPs, two case reports had this role $(3,31)$. The evidence derived from systematic review of case reports/series will be low, however such reviews can be used for clinical decision making (32). Hence the present review was undertaken with five case reports, which can provide early evidence and guidelines for future clinical trials on the outcome of single-visit REPs.

\section{Quality of Included Case Reports, Randomized Clinical Trial and Animal Study}

The quality of evidence derived from a review is largely dependent on the quality of the studies included. The quality assessment of included case reports are presented in Table 4. Five case reports scored "yes" for all 8-checklist questions. A good quality case report contains a clear and detailed description of a clinical condition; disease or treatment being described. A clear and systematic history following the timelines gives the reader a contextual relation and the importance of the condition being reported. Reports on an intervention should explain the procedure and provide vivid pre and post intervention clinical features with good quality pictures. Relevant and important investigative and diagnostic tests are reported along with their interpretations (18). Any anticipated or unexpected adverse events should be reported. Five included case reports in current review satisfied all eight questions, hence included case report was scored as high quality. The quality assessment of the included randomized clinical trial is shown in Table 5 . The included randomized clinical trial (25) was appraised as "some concerns" which could be due to bias in the randomization process. The study identified as a randomized clinical trial but failed to report on the method of randomization process and allocation concealment and hence were marked lower in quality. However, allocation concealment was not possible due to the inherent difference in methodology of the two interventions (immediate vs delayed induction). Inadequate randomization can lead to systemic differences between the experimental and control group of subjects and can lead to baseline differences. Allocation concealment conceals the experiment labels from the operator and the patients to avoid bias due to knowledge of the treatment or intervention. This can lead to spurious results affecting the magnitude and direction of the effect. Hooijmans et al. (20) developed the SYRCLE's risk of bias tool for animal studies and was adapted from the Cochrane's risk of bias tool. This tool evaluates the quality based on ten domains assessing five biases. In da Silva et al. (26) study domains 1 to 6 were scored as unclear (Table 6), however it should be mentioned that those were mostly related to animal husbandry and not necessarily relevant, considering that all groups were tested in each animal. Domain 7 to 10 were scored yes. The biases include selection, performance, detection, attrition and reporting. Selection bias can occur when randomization and allocation concealment are inadequate. Performance bias is dependent on random housing of the animals and blinding of the caregivers and operators. Detection bias occurs due to inadequate selection of animals for outcome assessment and blinding of the examiners. Attrition bias is related to incomplete or uneven loss of animals or exclusions. Selection of reported outcomes leads to reporting bias (20).

\section{Pre-Operative Factors}

The age of patients ranged from 7 to 12 in case reports, whereas in the randomized clinical trial from 6 to 
25 (at screening stage). Case reports and the randomized clinical trial included both genders, however the divide was not clearly reported for the latter study. Regarding type of teeth, for case reports, mandibular teeth were most commonly treated including a central incisor $(n=1)$, second premolars $(n=2)$ and mandibular first molars $(n=3)$, and finally, a maxillary central incisor $(n=1)$. In the animal study second and third maxillary premolars and second, third, and fourth mandibular premolars immature teeth were studied. The aetiology of the loss of vitality included caries $(n=5)$, dens invaginatus $(n=1)$, root fracture $(n=1)$ and dental avulsion $(n=1)$. In the animal study pulp necrosis and apical periodontitis was created experimentally. For the randomized clinical trial tooth type and aetiology of loss of vitality were not clearly stated. However, the four successful single visit cases were associated with trauma. The diagnosis of the teeth was necrotic pulp with periapical abscess or apical periodontitis for the randomized clinical trial (25) (personal communication with Dr. Tatiana Botero) and for most case reports, apart from the two studies, which included four teeth in total $(22,24)$. Partial necrosis was reported in one case report, in the presence of an invagination (21).

\section{Disinfection Strategies}

The presence of infection has a negative impact on the outcome of REPs (33), hence disinfection of the root canal system plays a major role. Generally, $\mathrm{NaOCl}$ in copious volumes was used for root canal irrigation in all included studies, at concentrations ranging from $2.5 \%$ to

Table 1. Characteristics of included case reports

\begin{tabular}{|c|c|c|c|c|c|c|c|c|}
\hline Author, year & Country & $\begin{array}{c}\text { Age } \\
\text { (years) }\end{array}$ & Gender & Study design & Tooth type & $\begin{array}{l}\text { Etiology of the } \\
\text { loss of vitality }\end{array}$ & \multicolumn{2}{|c|}{ Preoperative radiographic findings } \\
\hline $\begin{array}{l}\text { Shin et al. } \\
2009 \text { (21) }\end{array}$ & USA & 12 & Female & Case report & $\begin{array}{l}\text { Mandibular } \\
\text { second } \\
\text { premolar }\end{array}$ & $\begin{array}{l}\text { Caries } \\
\text { and dens } \\
\text { invaginatus }\end{array}$ & \multicolumn{2}{|c|}{$\begin{array}{l}\text { Immature open apex, measuring } 2 \mathrm{~mm} \text { in } \\
\text { diameter. Condensing osteitis at the apical } \\
\text { area with a large periradicular rarefaction } \\
9 \mathrm{x} \cdot 9 \mathrm{~mm} \text { in size, extending from the } \\
\text { apex to the distal crestal bone area }\end{array}$} \\
\hline $\begin{array}{l}\text { McCabe et al. } \\
2014 \text { (10) }\end{array}$ & Ireland & 7 & Female & Case report & $\begin{array}{l}\text { Maxillary } \\
\text { central } \\
\text { incisor }\end{array}$ & $\begin{array}{l}\text { Trauma, } \\
\text { oblique root } \\
\text { fracture }\end{array}$ & \multicolumn{2}{|c|}{$\begin{array}{l}\text { Probable periapical disease with } \\
\text { an incomplete root development } \\
\text { with wide open apex }\end{array}$} \\
\hline $\begin{array}{l}\text { Topcuoglu and } \\
\text { Topcuoglu, } \\
2016(24)\end{array}$ & Turkey & $8,8,9$ & $\begin{array}{l}\text { Female: } \\
\text { 2, } \\
\text { Male:1 }\end{array}$ & $\begin{array}{l}\text { Case } \\
\text { reports } \\
(\mathrm{n}=3)\end{array}$ & $\begin{array}{l}\text { Mandibular } \\
\text { first molars }\end{array}$ & Caries & \multicolumn{2}{|c|}{$\begin{array}{l}\text { Healthy periapical tissues with incomplete } \\
\text { root development with wide open apices }\end{array}$} \\
\hline \multicolumn{9}{|l|}{ Continuation } \\
\hline Author, year & $\begin{array}{r}\text { Pulpal } \\
\text { Peria| } \\
\text { pretrea } \\
\text { diagn }\end{array}$ & $\begin{array}{l}\text { and } \\
\text { ical } \\
\text { tment } \\
\text { osis }\end{array}$ & \multicolumn{2}{|c|}{$\begin{array}{l}\text { Disinfection } \\
\text { Protocol }\end{array}$} & $\begin{array}{c}\text { Intracanal } \\
\text { coronal barrier }\end{array}$ & $\begin{array}{l}\text { Duration of } \\
\text { Follow up }\end{array}$ & Clinical outcome & $\begin{array}{l}\text { Radiographic } \\
\text { outcome }\end{array}$ \\
\hline $\begin{array}{l}\text { Shin et al. } \\
2009(21)\end{array}$ & $\begin{array}{l}\text { Partially } \\
\text { pulp with } \\
\text { periapical }\end{array}$ & $\begin{array}{l}\text { necrotic } \\
\text { chronic } \\
\text { abscess }\end{array}$ & \multicolumn{2}{|c|}{$\begin{array}{l}10 \mathrm{~mL} \text { of } 6 \% \mathrm{NaOCl} \\
\text { saline, } 10 \mathrm{~mL} \text { of } 2 \% \\
\text { CHX for } 5 \text { minutes }\end{array}$} & $\begin{array}{l}\text { White MTA } \\
\text { (Dentsply Tulsa } \\
\text { Dental, Tulsa, } \\
\text { OK, USA) }\end{array}$ & $\begin{array}{l}\text { 2, } 3 \text { week, } 7 \text {, } \\
13,19 \text { months }\end{array}$ & $\begin{array}{l}\text { No tenderness } \\
\text { to percussion } \\
\text { or palpation, } \\
\text { Periodontal } \\
\text { pocket depths and } \\
\text { physiologic mobility } \\
\text { were normal. }\end{array}$ & $\begin{array}{c}\text { Complete } \\
\text { periradicular } \\
\text { bone healing and } \\
\text { root maturation, } \\
\text { complete resolution } \\
\text { of condensing } \\
\text { osteitis }\end{array}$ \\
\hline $\begin{array}{l}\text { McCabe et } \\
\text { al. } 2014 \text { (10) }\end{array}$ & $\begin{array}{r}\text { Necroti } \\
\text { with acut } \\
\text { periodo }\end{array}$ & $\begin{array}{l}\text { pulp } \\
\text { e apical } \\
\text { ntitis }\end{array}$ & \multicolumn{2}{|c|}{$\begin{array}{l}30 \mathrm{ml} \text { of } 5 \% \mathrm{NaOCl} \\
\text { for } 20 \text { minutes, } \\
\text { ultrasonics, } 3 \mathrm{ml} \text { of } \\
17 \% \mathrm{EDTA} \text {, final } \\
\text { rinse } 3 \mathrm{~mL} \mathrm{NaOCl} \\
\text { and } 3 \mathrm{~mL} \text { EDTA }\end{array}$} & $\begin{array}{l}\text { MTA plug (MTA; } \\
\text { Angelus,Londrina, } \\
\text { PR, Brazil) }\end{array}$ & $\begin{array}{l}6 \text { weeks, } 3 \\
6,12,18 \\
\text { months }\end{array}$ & Asymptomatic & $\begin{array}{l}\text { Evidence of } \\
\text { continued root } \\
\text { development. }\end{array}$ \\
\hline $\begin{array}{l}\text { Topcuoglu and } \\
\text { Topcuoglu, } \\
2016 \text { (24) }\end{array}$ & Necroti & pulp & \multicolumn{2}{|c|}{$\begin{array}{l}20 \mathrm{ml} \text { of } 2.5 \% \\
\mathrm{NaOCl}, 10 \mathrm{ml} \text { of } \\
\text { sterile saline, } 10 \\
\mathrm{ml} \text { of } 17 \% \text { EDTA }\end{array}$} & $\begin{array}{l}\text { Platelet- } \\
\text { rich plasma, } \\
\text { Biodentine } \\
\text { (Septodont, } \\
\text { Saint Maur des } \\
\text { Fosses, France) }\end{array}$ & $\begin{array}{l}\text { Every } 3 \\
\text { months } \\
\text { during an } \\
\text { 18-month } \\
\text { period }\end{array}$ & $\begin{array}{l}\text { Not sensitive } \\
\text { to percussion } \\
\text { or palpation, } \\
\text { physiologic mobility } \\
\text { and normal } \\
\text { probing depth } \\
\text { around the teeth }\end{array}$ & $\begin{array}{l}\text { Absence of } \\
\text { periapical lesions } \\
\text { and thickening of } \\
\text { the canal walls } \\
\text { and apical closure }\end{array}$ \\
\hline
\end{tabular}


$6 \%$. The lower concentration was used for three cases in the absence of radiographic signs of apical periodontitis (24), the randomized clinical trial and the animal study. In a previous systematic review, 97\% of the clinical studies used $\mathrm{NaOCl}$ as the only irrigant or in combination with other irrigating solutions in REPs (34).

Chlorhexidine was used in association with $\mathrm{NaOCl}$ and ethylenediaminetetraacetic acid (EDTA) in two studies $(21,22)$. EDTA was commonly used, with the exception of a case report (21) and the animal study (26). 17\% EDTA has the ability to promote the survival of stem cells of the apical papilla (35), reverse the adverse effect on $\mathrm{NaOCl}$ (36) and expose the dentin matrix to release growth factors $(37,38)$. Agitation of this solution was carried out in one study using ultrasonication (10), whereas one case report (23) and the animal study (26) used apical negative pressure with the EndoVac system. Ultrasonic activation significantly reduces the bacteria load in root canal system compared to conventional syringe irrigation methods (39). One animal model study showed that no difference was observed in terms of bacterial load reduction between EndoVac system to conventional irrigation combined with triple antibiotic paste in immature teeth with apical periodontitis (40). Further research has to be performed to confirm the ability of various irrigant agitation techniques and devices in REPs.

Table 2. Characteristics of included RCT

\begin{tabular}{|c|c|c|c|c|c|c|c|c|c|c|}
\hline $\begin{array}{l}\text { Author, } \\
\text { year }\end{array}$ & Country & $\begin{array}{l}\text { Age } \\
\text { (years) }\end{array}$ & Gender & $\begin{array}{l}\text { Study } \\
\text { design }\end{array}$ & $\begin{array}{l}\text { Tooth } \\
\text { type }\end{array}$ & $\begin{array}{l}\text { Clinical } \\
\text { condition }\end{array}$ & \multicolumn{2}{|c|}{ Sample size } & \multicolumn{2}{|c|}{ Disinfection Protocol } \\
\hline $\begin{array}{l}\text { Botero et } \\
\text { al. } 2017 \\
(25)\end{array}$ & USA & 6 to 25 & $\begin{array}{c}\text { Not } \\
\text { specified }\end{array}$ & $\begin{array}{r}\text { Randomi } \\
\text { Clinica } \\
\text { Trial }\end{array}$ & $\begin{array}{l}\text { Not } \\
\text { specified }\end{array}$ & $\begin{array}{l}\text { Pulp necrosis } \\
\text { on an } \\
\text { immature } \\
\text { permanent } \\
\text { tooth }\end{array}$ & $\begin{array}{l}13 \text { at randomi } \\
9 \text { intra-canal b }\end{array}$ & $\begin{array}{l}\text { zation; } \\
\text { leeding }\end{array}$ & \multicolumn{2}{|c|}{$\begin{array}{l}20 \mathrm{~mL} \text { of } 2.5 \% \mathrm{NaOCl} \text {, } \\
3 \mathrm{ml} \text { of saline, } 3 \mathrm{ml} \\
\text { of } 17 \% \text { EDTA for no } \\
\text { less than } 2 \text { minutes }\end{array}$} \\
\hline \multicolumn{11}{|l|}{ Continuation } \\
\hline $\begin{array}{l}\text { Author, } \\
\text { year }\end{array}$ & \multicolumn{2}{|c|}{$\begin{array}{c}\text { Etiology for the loss } \\
\text { of tooth vitality }\end{array}$} & \multicolumn{2}{|c|}{$\begin{array}{c}\text { intracanal } \\
\text { coronal barrier }\end{array}$} & $\begin{array}{l}\text { Follow-up } \\
\text { duration }\end{array}$ & $\begin{array}{l}\text { Radiographic } \\
\text { findings }\end{array}$ & $\begin{array}{l}\text { Clinical outcome } \\
\text { for success }\end{array}$ & \multicolumn{2}{|c|}{$\begin{array}{l}\text { Radiographic } \\
\text { outcome for success }\end{array}$} & $\begin{array}{l}\text { Success } \\
\text { rate }\end{array}$ \\
\hline $\begin{array}{l}\text { Botero et } \\
\text { al. } 2017 \\
(25)\end{array}$ & Not sp & ecified & $\begin{array}{r}\text { Whit } \\
\text { (Pro } \\
\text { Dentsp } \\
\text { Denta } \\
\text { OK, }\end{array}$ & $\begin{array}{l}\text { MTA } \\
\text { Root; } \\
\text { y Tulsa } \\
\text { Tulsa, } \\
\text { USA) }\end{array}$ & $\begin{array}{l}4 \text { weeks, } \\
3,12,24 \\
\text { months }\end{array}$ & $\begin{array}{l}\text { At least } 1 \\
\text { open apex of } \\
1 \mathrm{~mm} \text { or more } \\
\text { in diameter. } \\
\text { Periapical } \\
\text { radiolucency }\end{array}$ & $\begin{array}{l}\text { Absence of signs } \\
\text { or symptoms }\end{array}$ & $\begin{array}{r}\text { Dec } \\
\text { periar }\end{array}$ & $\begin{array}{l}\text { rease of } \\
\text { ical lesion }\end{array}$ & $\begin{array}{c}50 \% \\
\text { when } \\
\text { intracanal } \\
\text { bleeding } \\
\text { occurred }\end{array}$ \\
\hline
\end{tabular}

Table 3. Characteristics of included animal study

\begin{tabular}{|c|c|c|c|c|c|c|c|}
\hline $\begin{array}{l}\text { Author, } \\
\text { year }\end{array}$ & Country & $\begin{array}{c}\text { Age } \\
\text { (month) }\end{array}$ & $\begin{array}{l}\text { Study } \\
\text { design }\end{array}$ & $\begin{array}{l}\text { Number } \\
\text { of } \\
\text { samples }\end{array}$ & Animal species & Tooth type & Intervention \\
\hline $\begin{array}{l}\text { da Silva } \\
\text { et al. } 2010 \\
\quad(24)\end{array}$ & Brazil & 4 & $\begin{array}{l}\text { Animal } \\
\text { study }\end{array}$ & $\begin{array}{l}28 \text { root } \\
\text { canals }\end{array}$ & Mongrel dogs & $\begin{array}{c}\text { Second and third } \\
\text { maxillary premolars } \\
\text { and second, third, and } \\
\text { fourth mandibular } \\
\text { premolars }\end{array}$ & $\begin{array}{c}\text { Minimal mechanical } \\
\text { instrumentation using } 2.5 \% \\
\mathrm{NaOCl} \text { at each change of file. } \\
10 \mathrm{~mL} \text { of } 2.5 \% \mathrm{NaOCl} \text { using } \\
\text { apical negative pressure } \\
\text { (EndoVac System, Discus } \\
\text { Dental, Ontario, CA, USA) }\end{array}$ \\
\hline \multicolumn{8}{|l|}{ Continuation } \\
\hline $\begin{array}{l}\text { Author, } \\
\text { year }\end{array}$ & \multicolumn{3}{|c|}{$\begin{array}{l}\text { Preoperative radiographic } \\
\text { findings }\end{array}$} & \multicolumn{2}{|c|}{ Intracanal coronal barrier } & Duration of Follow up & Histological outcome \\
\hline $\begin{array}{l}\text { da Silva } \\
\text { et al. } 2010 \\
\quad(24)\end{array}$ & \multicolumn{3}{|c|}{$\begin{array}{c}\text { Incomplete root formation } \\
\text { and open apices. Periapical } \\
\text { periodontitis as indicated by } \\
\text { periapical radiolucencies }\end{array}$} & \multicolumn{2}{|c|}{$\begin{array}{l}\text { ProRoot grey MTA (Dentsply } \\
\text { Tulsa Dental, Johnson City, } \\
\text { TN, USA) and silver amalgam } \\
\text { (Sybraloy; Kerr Corporation, } \\
\text { Orange, CA, USA) }\end{array}$} & 3 months & $\begin{array}{l}\text { Intracanal connective tissue } \\
\text { ingrowth in all specimen and } \\
\text { beginning of mineralisation. } \\
\text { Normal alveolar bone } \\
\text { in } 20 \text { teeth, osteoclasts } \\
\text { present in the remaining }\end{array}$ \\
\hline
\end{tabular}




\section{Intra-Coronal Barrier Materials}

Among the seven included studies, five studies used MTA whereas two studies, used Biodentine as an intracoronal barrier. The MTA have been recommended in REPs due to its biocompatibility, sealing ability and tissue-conductive properties $(41,42)$. The disadvantage of using MTA is occurrence of mild or moderate tooth discoloration after single-visit REPs was reported in a case report (23) and the randomized clinical trial (25). Conversely, the use of Biodentine was justified in two studies $(22,24)$, in order to prevent this treatment complication. Further in vitro and in vivo studies have to be performed to study the potential use of other bioactive endodontic cements for REPs.

\section{Outcomes}

The limited evidence related to the component studies suggests that single-visit REPs are unpredictable, considering that the success rate reported in the randomized clinical trial was $50 \%$, which is lower than the multiple visit success rate comparator in the same study (25) and the success rates suggested in a previous systematic review for REPs (8). Although case reports were associated with successful treatment outcomes, it should be noted that these studies should not be used to assess treatment outcomes per se, considering that case reports presenting positive reports are more likely to be published (43).

REPs outcomes are likely influenced by the duration of follow up of the studies, as healing of apical periodontitis and root maturation, would require time. The final recall for the clinical studies ranged between 18 and 24 months (Tables 1 and 2), whereas the animal study had a 3-month recall only, with favorable histological results, also when compared with the multiple-visit group in the same study (Table 3). It should be highlighted that animal studies present with experimentally induced disease, whereas a well-established pathosis is commonly found in humans.
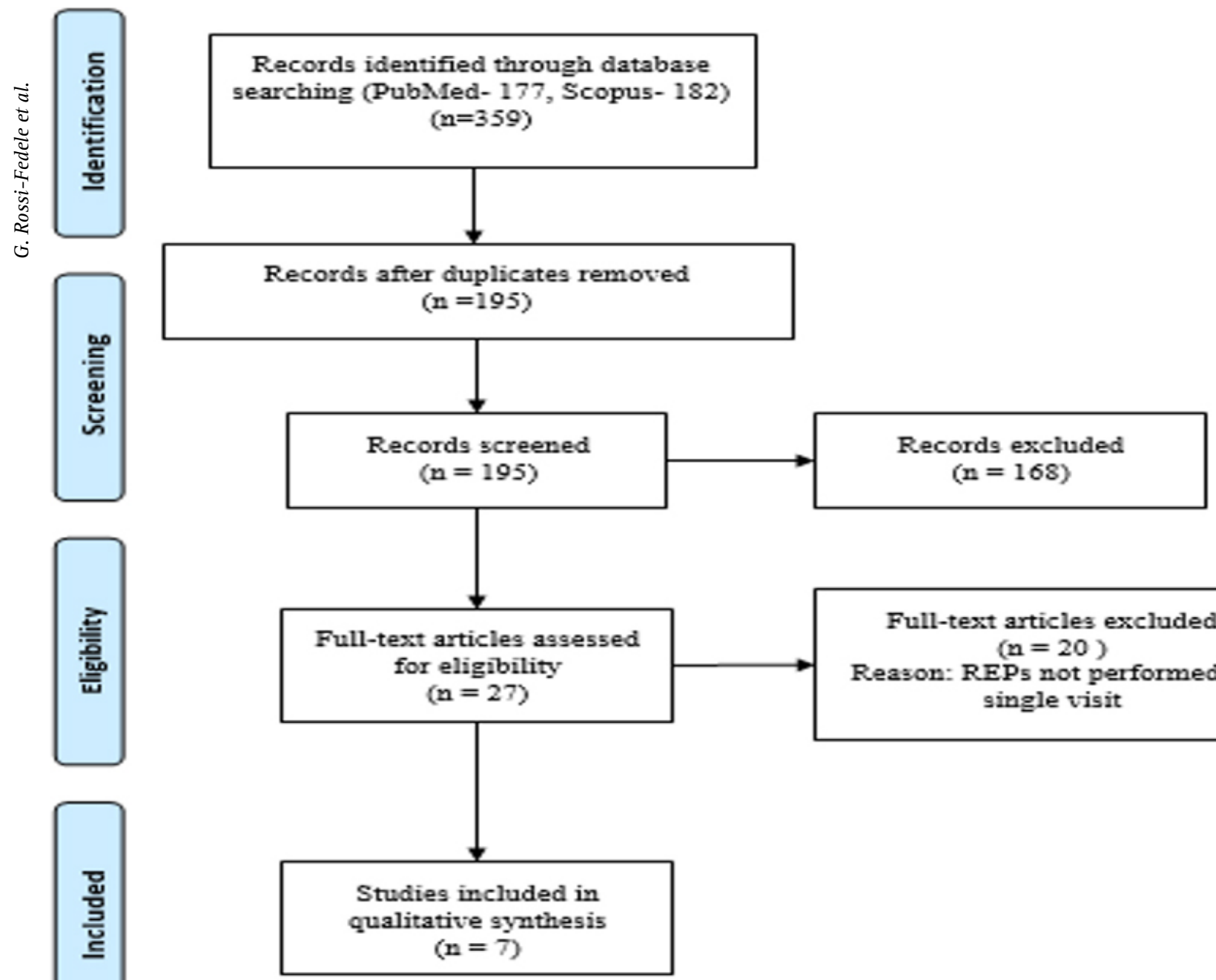

Full-text articles excluded $(n=20)$

Reason: REPs not performed in single visit

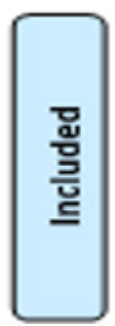

Figure 1. Summary of the details and results of the search process. 
Therefore the result of animal studies may not have the proposed clinical translation.

The definition of success differed widely amongst component studies (Tables 1 and 2). The clinical studies included symptoms and/or clinical signs, together with inconsistent radiographic criteria. The latter included further root maturation using various descriptors, associated with the reduction and/or disappearance of apical periodontitis, if previously present. Studies on patients did not include histological assessment, for obvious ethical reasons.

\section{Limitations of the Study}

The included studies have several confounding factors in their study design which may influence on outcomes, as previously described. Only publications in English language were included in our review and no grey literature was searched, which may be a limitation in the study selection process. This may have reduced the number of potentially eligible studies.

\section{Clinical Translation}

REPs protocols, in general, include limited or no instrumentation and no root canal obturation. Therefore, in the absence of medication, irrigation is crucial for the management of intra-canal infection, especially in the presence of apical periodontitis. The use of high concentrations of $\mathrm{NaOCl}$ followed by EDTA, in association with agitation, should therefore be considered for single-

Table 6. SYRCLE's tool for assessing risk of bias for animal study

\begin{tabular}{lcc}
\hline No & Domain & da Silva et al. 2010 (26) \\
\hline 1 & Sequence generation & Unclear \\
2 & Baseline characteristics & Unclear \\
3 & Allocation concealment & Unclear \\
4 & Random housing & Unclear \\
5 & Blinding & Unclear \\
6 & Random outcome assessment & Unclear \\
7 & Blinding & Yes \\
8 & Incomplete outcome data & Yes \\
9 & Selective outcome reporting & Yes \\
10 & Other sources of bias & Yes \\
\hline
\end{tabular}

Table 4. JBI Critical Appraisal Checklist for Case reports

\begin{tabular}{|c|c|c|c|c|c|}
\hline JBI checklist questions & $\begin{array}{l}\text { Shin et al. } \\
2009(21)\end{array}$ & $\begin{array}{l}\text { McCabe et } \\
\text { al. } 2014 \text { (10) }\end{array}$ & $\begin{array}{l}\text { Topcuoglu and } \\
\text { Topcuoglu } \\
2016(24) \\
\end{array}$ & $\begin{array}{l}\text { Chaniotis } \\
2016(23)\end{array}$ & $\begin{array}{l}\text { Aldakak et } \\
\text { al. } 2016(22)\end{array}$ \\
\hline $\begin{array}{l}\text { Were patient's demographic } \\
\text { characteristics clearly described? }\end{array}$ & Yes & Yes & Yes & Yes & Yes \\
\hline $\begin{array}{l}\text { Was the patient's history clearly described } \\
\text { and presented as a timeline? }\end{array}$ & Yes & Yes & Yes & Yes & Yes \\
\hline $\begin{array}{l}\text { Was the current clinical condition of the } \\
\text { patient on presentation clearly described? }\end{array}$ & Yes & Yes & Yes & Yes & Yes \\
\hline $\begin{array}{l}\text { Were diagnostic tests or assessment methods } \\
\text { and the results clearly described? }\end{array}$ & Yes & Yes & Yes & Yes & Yes \\
\hline $\begin{array}{l}\text { Was the intervention(s) or treatment } \\
\text { procedure(s) clearly described? }\end{array}$ & Yes & Yes & Yes & Yes & Yes \\
\hline $\begin{array}{l}\text { Was the post-intervention clinical } \\
\text { condition clearly described? }\end{array}$ & Yes & Yes & Yes & Yes & Yes \\
\hline $\begin{array}{l}\text { Were adverse events (harms) or unanticipated } \\
\text { events identified and described? }\end{array}$ & Yes & Yes & Yes & Yes & Yes \\
\hline Does the case report provide takeaway lessons? & Yes & Yes & Yes & Yes & Yes \\
\hline
\end{tabular}

Table 5. Revised Cochrane tool for assessing risk of bias for randomized clinical trial

\begin{tabular}{|c|c|c|c|c|c|c|}
\hline Author, year & $\begin{array}{l}\text { Bias arising } \\
\text { from the } \\
\text { randomization } \\
\text { process }\end{array}$ & $\begin{array}{l}\text { Bias due to } \\
\text { deviations } \\
\text { from intended } \\
\text { interventions }\end{array}$ & $\begin{array}{c}\text { Bias due } \\
\text { to missing } \\
\text { outcome data }\end{array}$ & $\begin{array}{l}\text { Bias in } \\
\text { measurement of } \\
\text { the outcome }\end{array}$ & $\begin{array}{l}\text { Bias in selection } \\
\text { of the reported } \\
\text { result }\end{array}$ & Overall bias \\
\hline $\begin{array}{l}\text { Botero et al. } \\
2017 \text { (25) }\end{array}$ & $?$ & + & + & + & + & $?$ \\
\hline
\end{tabular}

+symbol means 'low risk of bias'; ? symbol means 'some concerns. 
visit REPs, however taking into account the purported risk from irrigant extrusion. Alternatively, single-visit REPs may be considered in those cases where the intra-canal bacterial load is considered limited, such as pulpal necrosis in the absence of clinical and radiographic manifestations of apical periodontitis. Successful single-visit REPs cases have been reported for the different types of teeth and aetiologies of pulp necrosis.

Successful single-visit REPs commonly incorporated effective irrigation protocols, including the use of the high concentrations of $\mathrm{NaOCl}$ and EDTA together with the use of suitable agitation techniques. The evidence supporting the potential use of single-visit REPs is scarce, thus further high quality randomized clinical trials are needed to support the management of immature teeth by single-visit REPs.

\section{Resumo}

Os protocolos clínicos de procedimentos endodônticos de revascularização comumente requerem múltiplas sessões. Entretanto, procedimentos em única sessão podem apresentar vantagens clínicas relacionadas ao paciente. 0 objetivo desta revisão sistemática foi avaliar os resultados clínicos dos procedimentos endodônticos de revascularização para o manejo de dentes permanentes imaturos realizados em única visita. Duas bases de dados eletrônicas (Scopus e PubMed) foram utilizadas, do seu início à julho de 2018, buscando estudos que avaliaram resultados de procedimentos endodônticos clínicos e/ou radiográficos, e/ou histológicos da revascularização em sessão única realizados em dentes permanentes imaturos com necrose pulpar. Relatos de casos, estudos em animais e estudos clínicos foram incluídos e avaliados quanto à qualidade e risco de viés. A qualidade dos relatos de casos foi avaliada utilizando-se a ferramenta própria de análise crítica do Instituto Joanna Briggs. A qualidade dos estudos clínicos randomizados controlados foi analisada pela ferramenta de risco de viés da Cochrane. 0 risco de viés para os estudos em animais foi mensurado utilizando-se a ferramenta SYRCLE. Os dados foram tabulados e a sintese narrativa foi utilizada para análise dos mesmos. Sete estudos satisfizeram os critérios de inclusão. Cinco foram classificados como relatos de casos, um como ensaio clínico randomizado e um outro como estudo em modelo animal. Este último apresentou alto risco de viés, enquanto o restante dos estudos mostrou baixo risco. A evidência que apoia a utilização potencial de procedimentos endodônticos de revascularização em sessão única é escassa. Os procedimentos endodônticos de revascularização em sessão única geralmente incluem o uso de altas concentrações de hipoclorito de sódio e EDTA, combinadas com o uso de sistemas de agitação. Assim, estudos clínicos com longos periodos de acompanhamento são necessários para confirmação dos resultados do presente estudo.

\section{References}

1. Cvek M. Prognosis of luxated non-vital maxillary incisors treated with calcium hydroxide and filled with gutta-percha. A retrospective study. Endod Dent Traumatol 1992;8:45-55.

2. Moreno-Hidalgo MC, Caleza-Jimenez C, Mendoza-Mendoza A, IglesiasLinares A. Revascularization of immature permanent teeth with apical periodontitis. Int Endod J 2014;47:321-331.

3. Banchs F, Trope M. Revascularization of immature permanent teeth with apical periodontitis: new treatment protocol? J Endod 2004;30:196-200.

4. Silveira CM, Sebrão CC, Vilanova LS, Sánchez-Ayala A. Apexification of an immature permanent incisor with the use of calcium hydroxide: 16-Year follow-up of a case. Case Rep Dent 2015; 2015:984590.

5. Pace R, Giuliani V, Nieri M, Di Nasso L, Pagavino G. Mineral trioxide aggregate as apical plug in teeth with necrotic pulp and immature apices: a 10-year case series. J Endod 2014;40:1250-1254.

6. Vidal K, Martin G, Lozano 0, Salas M, Trigueros J, Aguilar G. Apical closure in apexification: A review and case report of apexification treatment of an immature permanent tooth with Biodentine. J Endod 2016;42:730-734.

7. Bukhari S, Kohli MR, Setzer F, Karabucak B. Outcome of revascularization procedure: A retrospective case series. J Endod 2016;42:1752-1759.

8. Kahler B, Rossi-Fedele G, Chugal N, Lin LM. An evidence-based review of the efficacy of treatment approaches for immature permanent teeth with pulp necrosis. J Endod 2017;43:1052-1057.

9. Galler KM, Krastl G, Simon S, Van Gorp G, Meschi N, Vahedi B. European Society of Endodontology position statement: revitalization procedures. Int Endod J 2016;49:717-723.

10. McCabe P. Revascularization of an immature tooth with apical periodontitis using a single visit protocol: a case report. Int Endod J 2015;48:484-497.

11. Nosrat A, Homayounfar N, Oloomi K. Drawbacks and unfavourable outcomes of regenerative endodontic treatments of necrotic immature teeth: a literature review and report of a case. J Endod 2012;38:14281434.

12. Kahler B, Rossi-Fedele G. A review of tooth discoloration after regenerative endodontic therapy. J Endod 2016;42:563-569.

13. Andreasen JO, Farik B, Munksgaard EC. Long-term calcium hydroxide as a root canal dressing may increase risk of root fracture. Dent Traumatol 2002;18:134-137.

14. Ruparel N, Teixeira FB, Ferraz CCR, Diogenes A. Direct effect of intracanal medicaments on survival of stem cells of the apical papilla. J Endod 2012;38:1372-1375.

15. Berkhoff JA, Chen PB, Teixeira FB, Diogenes A. Evaluation of triple antibiotic paste removal by different irrigation procedures. J Endod 2014;40:1172-1177.

16. Manfredi M, Figini L, Gagliani M, Lodi G. Single versus multiple visits for endodontic treatment of permanent teeth. Cochrane Database Syst Rev 2016;12: CD005296.

17. Simon S, Rilliard F, Berdal A, Machtou P. The use of mineral trioxide aggregate in one-visit apexification treatment: a prospective study. Int Endod J 2007;40:186-197.

18. Moola S, Munn Z, Sears K, Sfetcu R, Currie M, Lisy K. Chapter 7: Systematic reviews of etiology and risk. In: Aromataris $E$, Munn $Z$ (Editors). Joanna Briggs Institute Reviewer's Manual. The Joanna Briggs Institute, 2017. Available from https://reviewersmanual.joannabriggs. org/. Accessed July 29, 2018.

19. Higgins JPT, Sterne JAC, Savović J, et al. A revised tool for assessing risk of bias in randomized trials. In: Chandler J, McKenzie J, Boutron I, Welch V. Editors. Cochrane Methods. Cochrane Database Syst Rev 10 (Suppl 1); 2016:29-31.

20. Hooijmans $C R$, Rovers $M M$, deVries RB, Leenaars $M$, Ritskes-Hoitinga $M$, Langendam MW. SYRCLE's risk of bias tool for animal studies. BMC Med Res Methodol 2014;26:14-43.

21. Shin SY, Albert JS, Mortman RE. One step pulp revascularization treatment of an immature permanent tooth with chronic apical abscess: a case report. Int Endod J 2009;42:1118-1126.

22. Aldakak MM, Capar ID, Rekab MS, Abboud S. Single-Visit Pulp revascularization of a nonvital immature permanent tooth using Biodentine. Iran Endod J 2016;11:246-249.

23. Chaniotis $A$. The use of a single step regenerative approach for the treatment of a replanted mandibular central incisor with severe resorption. Int Endod J 2016;49:802-812.

24. Topçuoğlu G, Topçuoğlu HS. Regenerative endodontic therapy in a single visit using platelet-rich plasma and Biodentine in necrotic and asymptomatic immature molar teeth: a report of 3 cases. J Endod 2016;42:1344-1346.

25. Botero TM, Tang X, Gardner R, Hu JCC, Boynton JR, Holland GR. Clinical evidence for regenerative endodontic procedures: immediate versus delayed induction? J Endod 2017;43:S75-81.

26. da Silva LA, Nelson-Filho P, da Silva RA, Flores DS, Heilborn C, Johnson $J D$, et al. Revascularization and periapical repair after endodontic treatment using apical negative pressure irrigation versus conventional irrigation plus triantibiotic intracanal dressing in dogs' teeth with 
apical periodontitis. Oral Surg Oral Med Oral Pathol Oral Radiol Endod 2010;109:779-787.

27. Aromataris $E_{1}$ Munn Z. Joanna Briggs Institute Reviewer's Manual. Section I. Introductory information. The Joanna Briggs Institute, 2017. Available from https://reviewersmanual.joannabriggs.org/. Accessed February 11, 2019

28. Nissen T, Wynn R. The clinical case report: a review of its merits and limitations. BMC Res Notes 2014;7:264.

29. Murad MH, Sultan S, Haffar S, Bazerbachi F. Methodological quality and synthesis of case series and case reports. BMJ Evid Based Med 2018;23:60-63.

30. Murad MH, Asi N, Alsawas M, Alahdab F. New evidence pyramid. Evid Based Med 2016;21:125-127.

31. Iwaya SI, Ikawa M, Kubota M. Revascularization of an immature permanent tooth with apical periodontitis and sinus tract. Dent Traumatol 2001;17:185-187.

32. Chambers $D$, Rodgers $M$, Woolacott $N$. Not only randomized controlled trials, but also case series should be considered in systematic reviews of rapidly developing technologies. J Clin Epidemiol 2009;62:1253-e60. e64.

33. Fouad AF. Microbial factors and antimicrobial strategies in dental pulp regeneration. J Endod 2017;43:S46-50.

34. Kontakiotis EG, Filippatos CG, Tzanetakis GN, Agrafioti A. Regenerative endodontic therapy: a data analysis of clinical protocols. J Endod 2015;41:146-154.

35. Trevino EG, Patwardhan AN, Henry MA, Perry G, Dybdal-Hargreaves N, Hargreaves KM, et al. Effect of irrigants on the survival of human stem cells of the apical papilla in a platelet-rich plasma scaffold in human root tips. J Endod 2011;37:1109-1115.

36. Martin DE, De Almeida JF, Henry MA, Khaing ZZ, Schmidt CE, Teixeira $F B$, et al. Concentration-dependent effect of sodium hypochlorite on stem cells of apical papilla survival and differentiation. J Endod 2014;40:51-55.

37. Galler KM, Buchalla W, Hiller K-D et al. Influence of root canal disinfectants on growth factor release from dentin. J Endod 2015;41:363-368.

38. Galler KM, Widbiller M, Buchalla W, Eidt A, Hiller KA, Hoffer PC, et al. EDTA conditioning of dentine promotes adhesion, migration and differentiation of dental pulp stem cells. Int Endod J 2016;49: 581-590.

39. Nagendrababu $V$, Jayaraman J, Suresh $A$, Kalyanasundaram $S$, Neelakantan P. Effectiveness of ultrasonically activated irrigation on root canal disinfection: a systematic review of in vitro studies. Clin Oral Investig 2018;22:655-670.

40. Cohenca N, Heilborn C, Johnson JD, Flores DS, Ito IY, da Silva LA. Apical negative pressure irrigation versus conventional irrigation plus triantibiotic intracanal dressing on root canal disinfection in dog teeth Oral Surg Oral Med Oral Pathol Oral Radiol Endod. 2010;109:e42-46.

41. Torabinejad $M$, Parirokh M. Mineral trioxide aggregate: a comprehensive literature review-part II: leakage and biocompatibility investigations. J Endod 2010;36:190-202.

42. Parirokh $\mathrm{M}$, Torabinejad M. Mineral trioxide aggregate: a comprehensive literature review--Part III: Clinical applications, drawbacks, and mechanism of action. J Endod 2010;36:400-413.

43. Musu D, Rossi-Fedele G, Campisi G, Cotti E. Ultrasonography in the diagnosis of bone lesions of the jaws: a systematic review. Oral Surg Oral Med Oral Pathol Oral Radiol 2016;122:e19-29.

Received February 13, 2019

Accepted May 3, 2019 